\title{
INOVASI TEKNOLOGI PAKAN HIJAUAN LOKAL SEBAGAI PAKAN SUPLEMEN DALAM MENINGKATKAN PRODUKSI SUSU KERBAU DI PEMATANG PANJANG KABUPATEN SIJUNJUNG
}

\author{
Elly Roza *), Salam N. Aritonang dan Afriani Sandra \\ Fakultas Peternakan Universitas Andalas \\ *)Email : elroz@ansci.unand.ac.id
}

\begin{abstract}
ABSTRAK
Kelompok Tani Durian Sakek merupakan salah satu kelompok tani yang memelihara ternak kerbau yang di perah susunya untuk dijadikan dadih, terletak di nagari Pematang Panjang, Kabupaten Sijunjung, Sumatera Barat. Ternak kerbau dipelihara secara sederhana dilepas di padang penggembalaan dengan kondisi kualitas pakan rendah sehingga produksi susu yang dihasilkan juga rendah. Hal ini bisa dilakukan dengan pemberian pakan suplemen dengan memanfaatkan sumber daya pakan lokal seperti daun singkong dengan kandungan protein yang tinggi dan banyak tersedia di daerah setempat. Kegiatan ini bertujuan untuk memberikan pengetahuan dalam inovasi teknologi pemanfaatan pakan hijauan lokal khususnya daun singkong sebagai pakan suplemen ternak kerbau untuk meningkatkan produksi susu kerbau sehingga akan meningkatkan pendapatan peternak, sedangkan target khusus diharapkan adalah menumbuhkan swadaya masyarakat dalam usaha pemanfaatan pakan hijauan lokal sebagai pakan ternak. Metode yang diterapkan adalah penyuluhan, pelatihan/percontohan dan diskusi serta bimbingan dan pembinaan. Hasil yang diperoleh dari kegiatan ini produksi susu meningkat 1.05 vs 1.09 liter/hari dan kualitas susu juga meningkat: lemak 5.75 vs $7.46 \%$, Protein 4.05 vs 5.25\%, SNF 10.66 vs $11.45 \%$, Total solid 16.39 vs 19.95 dan kadar air 83.60 vs 80.05\%. Dari kegiatan ini dapat diambil kesimpulan pemberian daun singkong sebagai pakan suplemen dalam bentuk pellet dapat meningkatkan produksi dan kualitas susu kerbau penghasil dadih, sehingga meningkatkan pendapatan peternak.
\end{abstract}

Kata Kunci: pakan hijauan lokal, pakan suplemen, produksi susu kerbau

\section{Utilization of Local Forage Feed Resources as Supplement Feed in Increasing Buffalo Milk Production in Pematang Panjang, Sijunjung District}

\begin{abstract}
The Durian Sakek Farmer Group is one of the farmer groups that raised buffaloes whose milk is milked for dadih, located in Nagari Pematang Panjang, Sijunjung Regency, West Sumatera. Buffalo cattle are kept simply released in natural pastures with low feed quality conditions and low milk production. It can be done through improving the quality of feed ingredients. The easiest way to do this is supplementing feeds by utilizing local forage such as cassava leaves with high protein content and widely available in the local area. This activity aims to provide knowledge in technological innovations in the use of local forage feed, especially cassava leaves as a feed supplement for buffalo cattle, so that it can increase buffalo milk production followed by increasing farmer income. The specific target is expected to be to foster community self-help in the utilization of local forage feed as animal feed. The method applied is counselling, training/pilot, discussion, guidance and coaching. The results obtained from this activity increased milk production by 1.05 vs 1.091 / day and milk quality also increased fat 5.75 vs $7.46 \%$, protein 4.05 vs $5.25 \%$, SNF 10.66 vs $11.45 \%$, Total solid 16.39 vs 19.95 and moisture 83.60 vs $80.05 \%$. The conclusion of this activity is the provision of cassava leaves as supplement feed in the pellets form can increase the production and quality of buffalo milk producing dadih.
\end{abstract}

Keywords: local forage, feed supplement, buffalo milk production 


\section{PENDAHULUAN}

Kelompok tani Durian Sakek terletak di Nagari Pematang Panjang, Kecamatan Sijunjung. Kabupaten Sijunjung, daerah ini merupakan salah satu Kabupaten/Kota di Provinsi Sumatera Barat dan sebagai pintu emas menuju ke Provinsi Jambi dan Riau sebagai pusat pertumbuhan kawasan Sumatera di masa mendatang. Secara geografis daerah ini terletak di daerah khatulistiwa dengan iklim tropis basah dengan suhu mak $37^{\circ} \mathrm{C}$ dan minimal $21^{\circ} \mathrm{C}$, dengan topografi dari datar bergelombang sampai berbukit dan di beberapa tempat ada yang curam dan bahkan sangat curam. Kelompok tani ini bergerak dalam bidang peternakan rakyat di mana kerbau mendominasi ternak yang dipelihara oleh sebagian besar peternak. Mata pencaharian sebagian besar dari mereka adalah bertani, sedangkan ternak kerbau hanya usaha sampingan, namun keberadaan ternak kerbau menurut pengakuan masyarakat setempat menjadi pelengkap bagi kesempurnaan hidup mereka. Dengan perkataan lain, keseharian mereka merasa belum lengkap jika tidak memiliki ternak kerbau, sehingga hampir setiap kepala keluarga di wilayah tersebut memiliki ternak kerbau minimal 2 ekor.

Oleh karena letak geografisnya berada pada ketinggian 1300 meter di atas permukaan laut dan curah hujan rata-rata $2400 \mathrm{~mm} /$ tahun $(>9$ bulan basah) serta memiliki bentangan wilayah berbukit dan bergelombang, maka wilayah ini dapat dijadikan salah satu sentral produksi susu kerbau dan dadih di Sumatera Barat. Terlebih jika ditinjau dari lahan pertanian yang cukup luas dan subur, dan dapat ditanami hijauan untuk makanan ternak. Namun yang menjadi permasalahannya adalah pemeliharaan yang masih tradisional tanpa memperhatikan manajemen pemeliharaan terutama dalam pemberian pakan. Dalam kesehariannya hampir semua peternak melepaskan kerbau peliharaannya di lapangan bebas dan sore hari ternak tersebut kembali ke kandangnya dan ada yang tanpa kandang, ternak hanya diikat di belakang rumah petani dan belum biasa memberikan pakan tambahan serta penerapan aspek teknis pemeliharaan baru mencapai 40\% (Aritonang dan Roza, 2010).

Adapun lahan yang tersedia sebagian besar sudah di manfaatkan untuk lahan pertanian, yang merupakan sumber kehidupan mereka, sedangkan lahan hijauan/ rumput tidak banyak. Dengan sistem pemeliharaan seperti itu maka ransum yang di konsumsinya jauh dari yang dibutuhkan baik kualitas maupun kuantitasnya. Akibatnya, produksi susunya rendah dan dadih yang dihasilkan pun sedikit, padahal permintaan masyarakat terhadap dadih cukup tinggi, namun tidak dapat dipenuhi sehubungan produksi susu yang merupakan bahan baku dalam pembuatan dadih masih rendah.

Populasi ternak kerbau di Kecamatan Sijunjung 4.722 ekor ,diantaranya 319 ekor ternak kerbau penghasil dadih. Kepemilikan setiap kepala keluarga rata-rata 3 ekor dengan variasi 1-5 ekor, walau ada juga beberapa peternak yang memiliki 5-10 ekor dan bahkan ada yang memiliki $>20$ ekor. Pola pemeliharaan yang masih bersifat tradisional mengakibatkan rata-rata produksi susu untuk setiap ekor per hari sekitar 11.5 liter di luar susu yang di konsumsi langsung oleh anak kerbau/gudel yang baru dilahirkan. Di Sumatera Barat umumnya susu kerbau diolah menjadi dadih dengan cara diasamkan secara tradisional dalam tabung bambu. Produk dadih menyerupai yoghurt, tetapi proses pembuatannya tidak menggunakan ragi (bakteri starter) dan hanya disimpan dalam tabung bambu selama 2-3 hari dan siap untuk di konsumsi. 
Dadih berupa susu kental dengan rasa sedikit asam dan kadar kolesterol rendah yang merupakan makanan tradisional yang khas dan sangat digemari masyarakat Sumbar dan mempunyai nilai gizi yang tinggi, walau masih banyak juga yang tidak menyukainya. Untuk melestarikan keberadaan dan produksi dadih ini perlu adanya jaminan produksi susu kerbau yang optimal dan berkelanjutan. Susu yang di produksi setiap hari walaupun sedikit tetapi dapat meningkatkan pendapatan peternak, yaitu dengan mengolah menjadi dadih.

Upaya untuk memperbaiki produktivitas ternak kerbau yang dipelihara secara sederhana di lingkungan pedesaan dengan kualitas pakan rendah, dapat dilakukan melalui peningkatan kualitas bahan pakan. Cara yang sudah banyak dilakukan diantaranya melalui pemberian pakan suplemen berupa urea molasses multinutrient block (UMMB). Teknologi pakan suplemen ini diformulasikan dengan bahan-bahan seperti urea, molases, garam dan mineral serta bahan pakan lainnya yang tersedia di daerah setempat. Urea sebagai unsur non protein nitrogen dapat berperan meningkatkan status nutrisi dari pakan yang memiliki kualitas rendah

Akan tetapi hambatan dalam penggunaan UMMB sekarang ini adalah terbatasnya ketersediaan urea yang umumnya digunakan sebagai pupuk pertanian di daerah pedesaan, selain juga harganya mahal. Alternatif untuk mengatasi masalah tersebut adalah dengan memanfaatkan bahan lain yang dapat digunakan sebagai sumber protein seperti daun singkong. Daun singkong atau ubi kayu/ketela pohon (Manihot esculenta,Crantz) mempunyai potensi untuk dimanfaatkan sebagai komponen pengganti urea dalam pakan suplemen ini, di mana daun singkong yang telah dikeringkan (hay) merupakan sumber protein dan dapat dimanfaatkan sebagai suplemen pada nutrisi ruminansia terutama pada sapi perah, sapi pedaging dan kerbau. Adapun pemberiannya dapat secara langsung sebagai suplemen pakan dan sebagai sumber protein dalam konsentrat atau sebagai komponen bahan dalam pakan blok yang memiliki kualitas tinggi (Wanapat dan Khampa, 2006).

Daun singkong/ketela pohon kering mengandung protein $19.5 \%$ bahan kering dan tanin terkondensasi $4.0 \%$ bahan kering. Pemberian daun singkong kering pada kerbau lumpur sebanyak $1 \mathrm{~kg}$ bahan kering/ekor/hari nyata memperbaiki status nutrisi yang didasarkan pada kecernaan bahan kering, bahan organik, protein, konsumsi energi dan $\mathrm{NH}_{3}-\mathrm{N}$ rumen serta ekologi rumen. Selain itu, peranan tanin pada daun singkong tersebut dapat menurunkan jumlah telur cacing dalam feses sehingga status kesehatan ternak menjadi meningkat (Granum et al. 2007). Mengacu pada kandungan protein yang cukup tinggi pada daun singkong dan ketersediaan tanaman tersebut cukup banyak serta mudah diperoleh di pedesaan, maka potensi penggunaannya dalam pakan suplemen untuk menggantikan keterbatasan penggunaan urea sebagai sumber protein cukup tinggi. Sejauh ini, aplikasi teknologi pakan suplemen ini dengan memanfaatkan daun singkong belum pernah dilakukan pada ternak kerbau yang dipelihara secara tradisional di Sumatera Barat.

Tujuan dari kegiatan ini adalah memperkenalkan inovasi dan introduksi teknologi pakan suplemen dalam bentuk pellet untuk meningkatkan produksi dan kualitas susu kerbau. Target khusus yang diharapkan dari kegiatan ini adalah menumbuhkan swadaya masyarakat dalam usaha pemanfaatan pakan hijauan lokal sehingga akan meningkatkan produksi susu kerbau dan meningkatkan pendapatan peternak. 


\section{METODE}

Kegiatan ini dilaksanakan pada peternak kerbau yang di perah susunya untuk dijadikan dadih di kelompok tani Durian Sakek di Nagari Pematang Panjang Kabupaten Sijunjung selama 3 (tiga) bulan. Metode yang diterapkan adalah memberikan penyuluhan dan pelatihan/percontohan, pembinaan dan diskusi tentang pemanfaatan sumber daya pakan hijauan lokal yaitu daun singkong, yang mempunyai nilai gizi yang tinggi sebagai pakan ternak yang banyak terdapat di pedesaan yang belum dimanfaatkan sebagai pakan suplemen dalam bentuk pellet.

Metode penyuluhan merupakan cara yang paling tepat dalam memberikan pengetahuan kepada peternak dan diikuti dengan pelatihan. Untuk memantapkan pelaksanaan kegiatan ini disiapkan brosur/leaflet yang diberikan kepada setiap peserta sehingga materi penyuluhan lebih mudah dipahami dan dimengerti. Adapun materi yang diberikan adalah manajemen pemeliharaan ternak kerbau, pakan hijauan yang banyak di pedesaan seperti daun singkong yang mempunyai nilai gizi tinggi sebagai pakan suplemen dalam bentuk pellet.

Pelatihan/percontohan pembuatan pakan hijauan khususnya daun singkong sebagai pakan suplemen dalam bentuk pellet untuk ternak kerbau yang diperah susunya untuk dijadikan dadih. Peternak yang telah mulai menerapkan pemberian daun singkong dalam bentuk pellet sebagai pakan suplemen, akan dibimbing dan dibina yang dilakukan secara periodik melalui koordinasi dengan ketua kelompok. Pada saat penyuluhan, pelatihan/percontohan dan pembinaan, selalu diadakan diskusi dan konsultasi untuk lebih memantapkan kegiatan yang dilaksanakan Untuk melihat sejauh mana keberhasilan dan keefektifan kegiatan ini dapat diukur dengan menghitung produksi dan kualitas susu yang dihasilkan.

\section{HASIL DAN PEMBAHASAN}

Berdasarkan hasil pelaksanaan kegiatan yang telah dilakukan pada kelompok Tani Durian Sakek berupa penyuluhan dan demonstrasi/pelatihan terlihat para anggota kelompok cukup antusias mengikuti kegiatan ini, terbukti dengan banyaknya peserta yang hadir dan pertanyaan-pertanyaan yang diajukan oleh peserta. Setelah pelatihan dilakukan kelompok tani sudah mulai memanfaatkan sumber daya pakan lokal yaitu daun singkong sebagai pakan suplemen ternak kerbau dalam bentuk pellet yang dapat meningkat produk dan kualitas susu, serta pendapatan peternak juga meningkat.

Kelompok Tani Durian Sakek merupakan salah satu kelompok tani yang memelihara ternak kerbau yang di perah susunya untuk dijadikan dadih dan merupakan pekerjaan pokok yang sudah dijadikan sebagai penghasilan utama keluarga. Ternak yang dipelihara sudah ditargetkan untuk dadih yang dijual ke masyarakat setempat. Adapun pembelinya adalah konsumen yang kebetulan hanya melintas di jalan raya dan pedagang langsung menjemput ke peternak. Oleh karena produksi susu yang dihasilkan sedikit, maka sering permintaan konsumen akan dadih tidak dapat dipenuhi apalagi di hari libur dan acara-acara adat/keagamaan lalu lintas di sekitar produsen dadih cukup ramai. Susu yang di produksi setiap hari walaupun sedikit tetapi dapat meningkatkan pendapatan peternak, yaitu dengan mengolah menjadi dadih. 
Permintaan masyarakat terhadap dadih cukup tinggi, namun tidak dapat dipenuhi sehubungan produksi susu yang merupakan bahan baku dalam pembuatan dadih masih rendah. Pola pemeliharaan yang masih bersifat tradisional mengakibatkan rata-rata produksi susu untuk setiap ekor per hari sekitar 1-1.5 liter (Roza, 2013) di luar susu yang di konsumsi langsung oleh anak kerbau/gudel yang baru dilahirkan. Kepemilikan setiap kepala keluarga rata-rata 3 ekor dengan variasi 1-5 ekor, walau ada juga beberapa peternak yang memiliki 5-10 ekor dan bahkan ada yang memiliki $>20$ ekor.

Untuk memperbaiki produktivitas ternak kerbau yang dipelihara secara sederhana di lingkungan pedesaan khususnya di kelompok tani Durian Sakek dengan kondisi kualitas pakan rendah, dilakukan melalui peningkatan kualitas bahan pakan. Cara yang paling mudah dilakukan diantaranya melalui pemberian pakan suplemen dengan memanfaatkan sumber daya pakan lokal yaitu daun singkong dengan kandungan protein yang tinggi dan banyak tersedia di daerah setempat. Tim kegiatan dari Fakultas Peternakan melakukan kegiatan dengan memanfaatkan daun singkong sebagai pakan suplemen dalam bentuk pellet yang dapat meningkatkan produksi dan kualitas susu kerbau dengan biaya pakan rendah guna meningkatkan pendapatan peternak.

Daun singkong merupakan sumber protein dan dapat dimanfaatkan sebagai suplemen pada nutrisi ruminansia terutama pada sapi perah, sapi pedaging dan kerbau. Adapun pemberiannya dapat secara langsung sebagai suplemen pakan dan sebagai sumber protein dalam konsentrat atau sebagai komponen bahan dalam pakan blok yang memiliki kualitas tinggi.

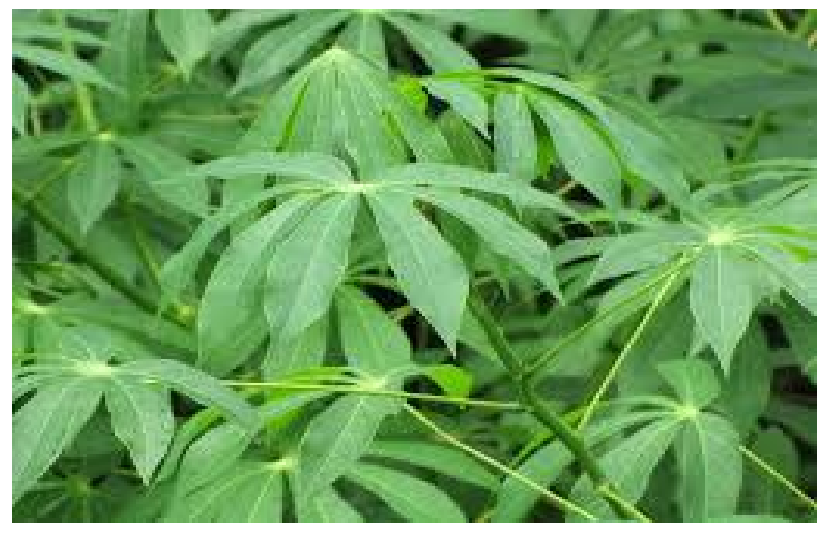

Gambar 1. Daun Singkong (Manihot esculenta,Crantz)

Strategi untuk meningkatkan konsumsi pakan oleh ternak pada kondisi pemeliharaan tradisional ialah dengan memberikan suplemen yang tersusun dari kombinasi bahan ilmiah sumber protein dengan tingkatan jumlah tertentu yang secara efisien dapat mendukung pertumbuhan, perkembangan dan kegiatan mikroba secara efisiensi dalam rumen. Selanjutnya produktivitas ternak dapat ditingkatkan dengan memberikan sumber $\mathrm{N}$ protein dan/ atau non protein serta mineral tertentu. Suplementasi secara keseluruhan diharapkan dapat memberikan pengaruh yang baik melalui peningkatan protein mikrobial, peningkatan daya cerna dan peningkatan 
konsumsi pakan hingga diperoleh keseimbangan yang lebih baik antara amino dan energi di dalam zat-zat makanan yang terserap.

Dalam pelaksanaan kegiatan ini, di samping cara pemeliharaan ternak, kepada petani peternak pun diberikan penjelasan dan peragaan bagaimana cara pemberian ransum yang dapat memenuhi kebutuhan ternak. Pada umumnya dalam pemberian makanan penguat atau disebut juga dengan konsentrat, masih banyak peternak yang belum melakukannya dengan tepat sehingga berpengaruh terhadap produksi susu. Pemanfaatan bahan pakan lokal dapat menjadi solusi bagi peternak, agar produksi susu yang dihasilkan tinggi dengan kualitas yang bagus dan sesuai standar (Moran, 2009). Pemanfaatan pakan lokal membantu meningkatkan manajemen pemeliharaan ternak dengan mengolah limbah hasil pertanian seperti amoniasi jerami jagung sehingga tidak mencemari lingkungan (Afriani dan Sefrtiadi, 2019).
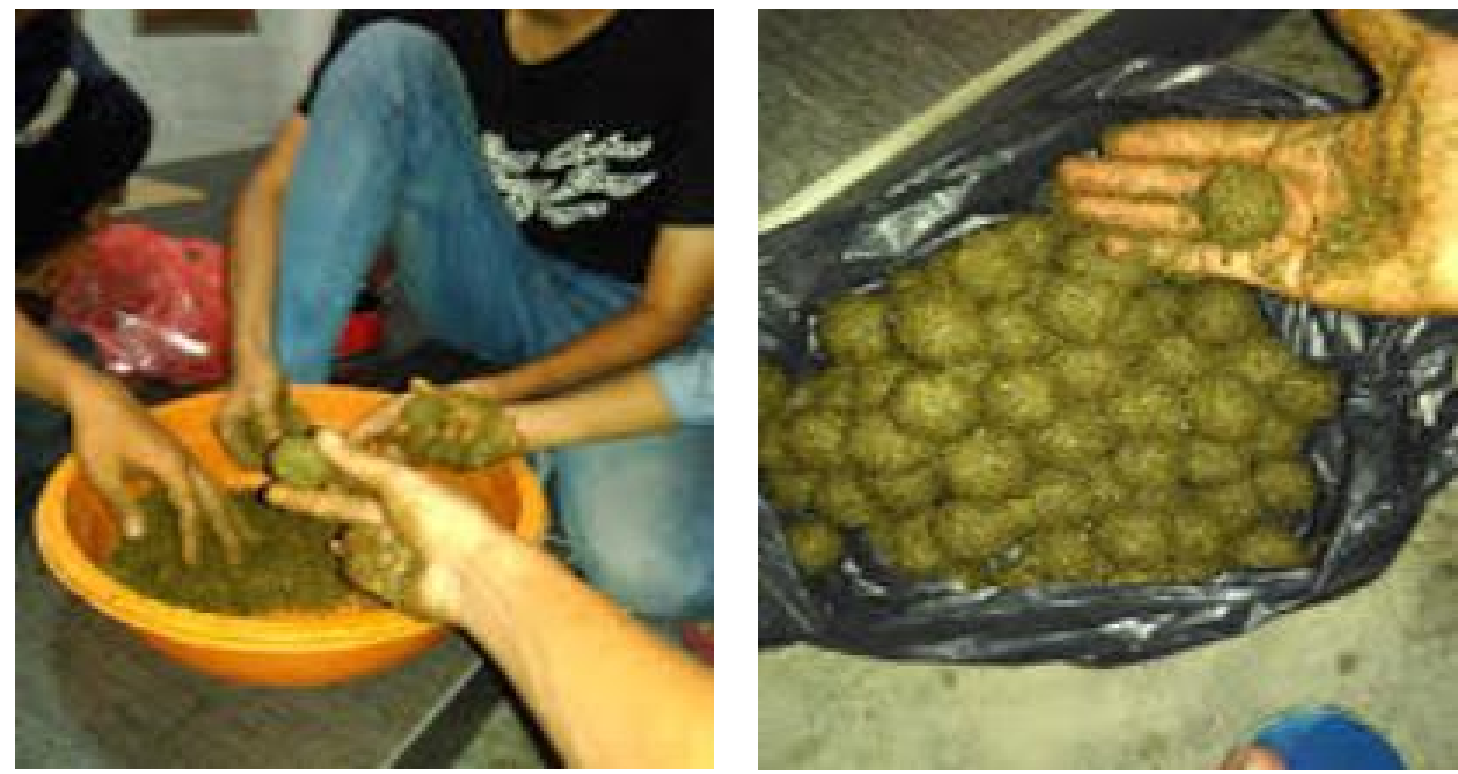

Gambar 2. Proses Pengolahan Daun Singkong Menjadi Pellet

Keterbatasan pengetahuan petani peternak dalam manajemen pemberian pakan disertai kurangnya manajemen pemeliharaan inilah yang menyebabkan produksi susu yang dihasilkan tidak optimum, demikian juga dengan kualitas susu yang dihasilkan sehingga memengaruhi rasa susu yang dihasilkan. Dengan memberikan suplemen yang tersusun dari kombinasi bahan ilmiah sumber protein dengan tingkatan jumlah tertentu yang secara efisien dapat mendukung pertumbuhan, perkembangan dan kegiatan mikroba secara efisien di dalam rumen. Selanjutnya produktivitas hewan dapat ditingkatkan dengan memberikan sumber $\mathrm{N}$ protein dan/ atau non protein serta mineral tertentu. Suplementasi secara keseluruhan diharapkan dapat memberikan pengaruh yang baik melalui peningkatan protein mikrobial, peningkatan daya cerna dan peningkatan konsumsi pakan hingga diperoleh keseimbangan yang lebih baik antara amino dan energi di dalam zat-zat makanan yang terserap.

Manajemen pemeliharaan khususnya manajemen pemberian pakan merupakan faktor kedua yang menjadi pembatas di kelompok Ternak Durian Sakek. 
Perbaikan manajemen ternak kerbau mutlak perlu dilakukan mengingat ternak kerbau merupakan ternak yang cukup berkembang di Sumatera Barat. Keberhasilan suatu usaha peternakan dengan memperbaiki manajemen pemeliharaan diharapkan dapat memperbaiki dan meningkatkan produktivitas ternak, sehingga setiap unit ternak dapat tumbuh lebih cepat dengan tingkat produksi dan reproduksi yang baik, usaha ini tergantung kepada mental dan keterampilan peternak dalam pemeliharaan ternak secara benar dan baik. Produktivitas yang rendah disebabkan oleh beberapa faktor, antara lain kualitas genetik ternak, tatalaksana pakan, umur pemerahan, masa kering kandang tata cara pemerahan, system perkandangan, sanitasi dan penyakit terutama mastitis. Kualitas susu sangat ditentukan oleh banyaknya kandungan kuman atau bakteri di dalamnya, karena kuman-kuman tersebut dapat merubah sifat kimia dan fisik susu (Roza et al., 2020)

Produksi dan kualitas susu yang dihasilkan selama kegiatan berlangsung dengan pemberian pakan suplemen daun singkong dalam bentuk pellet terjadi peningkatan seperti pada Tabel 1 .

Tabel 1. Produksi dan Komposisi Kimia Susu Kerbau Pada Kelompok Tani Durian Sakek di Nagari Pematang Panjang, Sijunjung

\begin{tabular}{lcc}
\hline \multicolumn{1}{c}{ Komponen } & Sebelum kegiatan & Nilai \\
Kadar Air (\%) & 83.60 & Sesudah kegiatan \\
Kadar Protein (\%) & 4.05 & 80.05 \\
Kadar Lemak (\%) & 5.73 & 5.25 \\
Laktosa (\%) & 3.37 & 7.46 \\
Bahan Kering Tanpa Lemak (\%) & 10.66 & 3.39 \\
Produksi susu (1/hr/ekor) & 1.09 & 11.95 \\
\hline
\end{tabular}

Terjadinya peningkatan produksi susu dengan pemberian pakan suplemen daun singkong dalam bentuk pellet karena kandungan protein, mineral serta vitamin yang terdapat pada daun singkong, unsur tersebut merupakan zat yang dibutuhkan untuk proses pembentukan susu kerbau (Roza, 2013). Wanapat (2000) manipulasi rumen dengan suplementasi daun singkong dapat meningkatkan konsumsi hijauan yang memiliki kualitas rendah dan meningkatkan produktivitas ternak ruminansia terutama produksi susu dan pertambahan bobot badan. Hasil penelitian Wanapat (2000) pemberian daun ubi kayu kering sebanyak $2 \mathrm{~kg} / \mathrm{hari}$ ditambah urea $3 \% \mathrm{mampu}$ meningkatkan kandungan lemak dan protein susu masing-masing 4.0 vs $4.6 \%$ dan 4.4 vs $5.3 \%$.

Peningkatan kadar potein susu kerbau meningkat dengan pemberian pakan suplemen daun singkong disebabkan oleh kandungan tanin terkondensasi dalam daun singkong yang berperan dalam membentuk tannin- protein kompleks dan meningkatkan protein by pass di dalam rumen, sehingga daun singkong sebagai sumber protein tambahan dapat meningkatkan produksi susu dan komposisi susu (Roza, 2013).

Meningkatnya Bahan kering tanpa Lemak (BKTL) pada susu kerbau yang diberi daun singkong, karena kandungan protein dan mineral yang terkandung pada daun singkong yang dibutuhkan untuk pembentukan protein dan laktosa susu. Protein dan laktosa susu merupakan komponen penyusun BKTL susu. Hal ini sesuai dengan 
pendapat (Zurriyanti et al., 2011), bahwa BKTL susu dipengaruhi oleh laktosa dan protein.

Meningkatnya kadar lemak susu kerbau yang diberi daun singkong sebagai pakan suplemen, disebabkan daun singkong merupakan pakan hijauan yang mengandung serat kasar $>14 \%$. Pada ternak perah konsumsi hijauan atau serat sangat penting dan berpengaruh terhadap kualitas susu khususnya lemak susu. Sesuai dengan pendapat Sudono et al.,(2003) pakan hijauan menyebabkan kadar lemak susu tinggi karena lemak susu tergantung dari kandungan serat kasar dalam pakan.

Menurunnya kadar air susu kerbau yang diberi daun singkong sebagai pakan suplemen dalam bentuk pellet karena kandungan protein dan serat kasar yang terkandung dalam daun singkong yang dibutuhkan untuk pembentukan protein, laktosa serta lemak dalam susu. Ketiga komponen tersebut merupakan bahan penyusun padatan dalam susu (total solid). Penyusun dari total solid dalam susu adalah protein, lemak, laktosa, vitamin, dan mineral semakin tinggi kandungan protein dan serat kasar yang terkandung dalam bahan kering pakan maka meningkat pula total padatan pada susu sehingga dapat menurunkan kadar air susu, karena pakan dapat memengaruhi kualitas susu yang dihasilkan. Kandungan bahan kering susu tergantung pada zat-zat makanan yang di konsumsi oleh ternak yang kemudian digunakan sebagai prekursor pembentukan bahan kering atau padatan di dalam susu (Roza, 2013).

Oleh sebab itu daun singkong atau ubi kayu (Manihot esculenta Cranz) mempunyai potensi untuk dimanfaatkan sebagai komponen pengganti urea dalam pakan suplemen. Dengan tercukupinya kebutuhan pakan yang diperlukan untuk ternak kerbau laktasi maka produksi dan kualitas susu yang dihasilkan meningkat, sehingga jumlah dadih yang dihasilkan juga meningkat tanpa ada rasa kekuatiran anak kerbaunya mengalami penurunan berat badan, oleh karena kebutuhan susunya sudah terpenuhi dengan pemberian pakan suplemen.

Melalui kegiatan ini diharapkan pengetahuan peternak bertambah tidak hanya dalam pemberian daun singkong sebagai pakan suplemen dalam bentuk pellet saja tetapi juga dapat memanfaatkan limbah hasil pertanian lainnya yang banyak ditemukan di sekitar peternakan. Biaya untuk pakan hijauan dapat dikurangi sehingga secara tidak langsung juga akan meningkatkan pendapatan peternak.

\section{Cara Pembuatan Pakan Suplemen TDS}

Dalam pembuatan pakan suplemen bahan-bahan yang digunakan adalah : urea, saka/gula tebu, dedak, tepung daun singkong (TDS), semen, mineral mix dan garam dapur Komposisi pakan suplemen dan bahan penyusunnya secara rinci dapat dilihat pada Tabel 2.

Proses pembuatan pakan suplemen adalah seluruh bahan pada formula yang dibuat dicampur kecuali Saka. Setelah bahan-bahan dicampur secara merata, kemudian saka dicampur dengan air dan dipanaskan kemudian ditambahkan ke dalam campuran dan diaduk-aduk hingga tidak ada gumpalan-gumpalan. Selanjutnya adonan DSB (Daun Singkong Blok) yang masih panas tersebut di pres dalam wadah-wadah atau cetakan dalam bentuk pellet. DSB telah siap untuk diberikan kepada hewan atau disimpan di tempat yang tidak lembap. 
Tabel 2. Komposisi Bahan dalam Pakan Suplemen Bentuk Pellet Menurut Komposisi Tepung Daun Singkong $(\mathrm{kg} / 10 \mathrm{~kg})$.

\begin{tabular}{lcc}
\hline \multirow{2}{*}{ Bahan } & \multicolumn{2}{c}{ Proporsi } \\
\cline { 2 - 3 } & \multicolumn{2}{c}{ Jml/10kg } \\
\hline Urea & 10 & 1 \\
Saka & 20 & 2 \\
Dedak padi & 45 & 4,5 \\
TDS* & 0 & 0 \\
Semen & 10 & 1 \\
Garam & 8 & 0,8 \\
Mineral-mix & 2 & 0,2 \\
Air & 5 & 0,5 \\
\hline & 100 & 10 \\
\hline
\end{tabular}

Keterangan : *) tepung daun singkong

\section{KESIMPULAN DAN SARAN}

Dari hasil pelaksanaan kegiatan yang telah dilakukan menunjukkan bahwa kegiatan ini sangat efektif dalam memberikan inovasi dan penerapan ilmu pengetahuan kepada peternak dengan metode penyuluhan, pelatihan, pembinaan dan diskusi. Peternak dapat memahami manfaat daun singkong dengan kandungan protein yang tinggi sebagai pakan suplemen dalam bentuk pellet di mana ketersediaan banyak di pedesaan dengan pemberian pakan suplemen dapat meningkatkan produksi dan kualitas susu yaitu produksi susu meningkat $1.05 \mathrm{vs} 1.09 \mathrm{l} / \mathrm{hr}$ dan kualitas susu juga meningkat: lemak 5.75 vs $7.46 \%$, Protein 4.05 vs $5.25 \%$, SNF 10.66 vs $11.45 \%$, Total solid 16.39 vs 19.95 dan kadar air 80.05 vs $83.60 \%$. Kesimpulan dari kegiatan ini adalah pemberian daun singkong sebagai pakan suplemen dalam bentuk pellet dapat meningkat produksi dan kualitas susu kerbau dengan biaya murah yang pada akhirnya meningkatkan produksi dadih dan pendapatan peternak.

\section{UCAPAN TERIMA KASIH}

Ucapan terima kasih dari Tim Pengabdian Masyarakat kepada Universitas Andalas yang telah mendanai kegiatan ini melalui Dana DIPA Universitas Andalas No. 644/XIII/A/Unand/2016 Tanggal 22 April 2016.

\section{DAFTAR PUSTAKA}

Afriani, T., dan Y. Seftiadi. 2019. Pemberdayaan masyarakat melalui pelatihan pembuatan pakan alternatif amoniasi jerami jagung di Nagari Pelangai Kaciak Kecamatan Ranah Pesisir, Pesisir Selatan. Warta Pengabdian Andalas. Vol 26 (2). 
Aritonang, S. N and E. Roza. 2010. Potency of fresh cassava leaves (Manihot esculenta crantz) as naural anthelminthic on goat performances. Pakistan Journal of Nutrition, Vol. 14 (6) : 358-361.

Granum, G., M. Wanapat, P. Pakdee, C. Wachirapakorn and W. Toburan. 2007. A comparative study on the effect of cassava hay supplementation in swamp buffaloes (Bubalus bubalis) and cattle (Bos indicus). Asian-Aust. J. Anim. Sci. 20(9): 1389-1396.

Moran J. 2009. Business Management for Tropical Dairy Farmers. Landlinks Press. Rohaeni, E.S., N.A. Sumanto, 2006. Pengkajian integrasi usahatani jagung dan ternak sapi di lahan kering Kabupaten Tanah Laut, Kalimantan Selatan. J.Pengkajian dan Pengembangan Teknologi Pertanian. Vol : 9 No.2 p : 129139.

Roza, E., S. N. Aritonang., H. Susanti dan A. Sandra. 2020. Sanitasi pemerahan dan kualitas susu di kelompok tani Harapan Makmur di Kecamatan Koto Tangah Kota Padang. Jurnal Hilirisasi IPTEKS, Vol 3 (1).

Roza, .E 2013. Pengaruh Penggunaan Daun Singkong Sebagai Pakan Suplemen Terhadap Performans Produksi dan Gejala Reproduksi Ternak Kerbau yang Diperah Dipelihara Secara Tradisional. Disertasi Bidang Ilmu Ternak. Fakultas Pertanian. Universitas Andalas, Padang.

Sudono, A., R. F. Rosdiana dan B. S. Setiawan. 2003. Beternak Sapi Perah Secara Intensif. Agromedia Pustaka, Jakarta.

Wanapat, M. 2000. Rumen manipulation to increase the efficient use of local feed resources and productivity of ruminant in the tropics. Asian-Aust. J. Anim. Sci. 13 (Suppl.): 59-67.

Wanapat, M dan S. Khampa. 2006. Effect of level of suplementation of concentrate containing high level of cassava chip on rumen ecology, microbial $\mathrm{N}$ supply and digestibility of nutrition in beef cattle. Abstract. Asian-Aust. J. Anim. Sci. 20 (1): $75-81$.

Zurriyanti, Y., R.R. Noor dan R.R.A. Maheswari. 2011. Analisis molekuler genotype kappa kasein ( K- Kasein) dan komposisi susu kambing Peranakan Ettawa, saanen dan persilangannya. JLTV, 16 (1): 61-70. 